\title{
Ownership Structure Impact on Dividend Policy of Listed Companies on Vietnamese Securities Market
}

\author{
Dang Trung Kien ${ }^{1}$, Yi-Pei Chen ${ }^{2}$ \\ ${ }^{1}$ College of Business, Chung Yuan Christian University, Taiwan \\ ${ }^{2}$ Department of Finance, College of Business, Chung Yuan Christian University, Taiwan \\ Email: *dangtrungkien.vn@gmail.com
}

How to cite this paper: Kien, D.T. and Chen, Y.-P. (2020) Ownership Structure Impact on Dividend Policy of Listed Companies on Vietnamese Securities Market. Journal of Mathematical Finance, 10, 223-241. https://doi.org/10.4236/jmf.2020.102014

Received: April 5, 2020

Accepted: May 5, 2020

Published: May 8, 2020

Copyright ( 2020 by author(s) and Scientific Research Publishing Inc. This work is licensed under the Creative Commons Attribution International License (CC BY 4.0).

http://creativecommons.org/licenses/by/4.0/

\section{(c) (i) Open Access}

\begin{abstract}
This research aims to investigate the relationship between ownership structure and dividend policy of Vietnamese listed companies. The empirical findings show that the government-controlled companies, the companies with high concentrated ownership and with recent right issue activities would have higher dividend payments. In addition, due to the change of Vietnamese dividend tax rate to encourage the market development after global economic crisis, we discover that when the personal income tax rate at higher level of $5 \%$, the sate-owned firms in Ho Chi Minh Stock Exchange would still pay higher dividends, which represents the dividend preferences of the investors, the status of firms' stable development and the effectiveness of national economic policies.
\end{abstract}

\section{Keywords}

Ownership, Dividend Policy, Government-Controlled, Personal Income Tax, Vietnamese Securities Market

\section{Introduction}

Dividend-payout policy is always considered as one of the most important decisions in financial management of company. The dividend payment may affect directly the interests of shareholders and the future development of a company. In a new security market as Vietnam, due to the information asymmetry, investors often rely on the dividend payment as a viewpoint to predict the company's future prospects.

Vietnamese security market, a new market with around two decades of 
founding only, was started by the establishment of its regulator, the State Securities Commission, in 1997. It became an indispensable premise to bring securities market to Vietnam, with the opening of the two currently national stock exchanges, Ho Chi Minh City Stock Exchange in July 2000, a trading platform for relatively large corporations' stock, and Hanoi Stock Exchange in March 2005 for relatively small and medium enterprises (SMEs') stocks. As expectation, the security market has worked well to push up the Vietnamese economic and maintain a high development speed. Until 2014, share market capitalization reaches close to $40 \%$ GDP of Vietnam, becoming the major channel for capital mobilization of both State-owned and private economic sector ${ }^{1}$.

Investors enjoy an attractive low-tax rate for dividends in Vietnam which currently is at $0 \%$ for institutional investors and $5 \%$ for individual ones. At the same time, to deal with global economic recession, the government applied the $0 \%$ dividend tax of individual in some specific period to encourage more active securities trades. Also, to maintain the market growth and keep an attractive share trading environment, the Vietnamese government is continuously improving their policies as well as the law and the market regulation. As a result, by the 2014 law, the time for dividends distribution now is even more restricted for business firms. It can be considered as a legal protection for shareholders. The authorities recognize that the dividend payout policy and its announcement are one of the most important considerations for stock trading decision of Vietnamese. Hence, they try to make the companies' dividend payouts a reliable signal in the capital market.

However, as a new market, challenges remain. As the majority of Vietnamese still calls it "playing stocks", trading stock is more likely to a gamble than an investment. It can be challenging to convince investors about the merits of investment principles, such as buy-and-hold, to identify and confirm the market signal for understanding the trade-movements. Joining the market, investors should analyze the company's financial status, its business activities, history and management. But, "about 30\% of investors jump in based on what other investors do, and the others $40 \%$ are investing on basic information."

Also, there is another problem about the way Vietnamese manages their economic. Especially for those state-owned enterprises (SOEs) or partly government-controlled firms, they are supported by the "Equitization" ${ }^{3 "}$ process, the transformation of all state-owned enterprise, the key role of the Vietnamese economic sectors to be joint-stock companies. According to Nguyen \& Van Dijk [1], they find that there is positive relation between the Vietnamese SOEs' growth and the corruption experienced by SOEs. This problem can be harmful for the government-controlled firms to play an important role in Vietnamese national economic strength. If corruption exists in SOEs, it can become practic-

${ }^{1}$ Hoang Phu Cuong, deputy director of State Security Commission (2014).

${ }^{2}$ Nguyen Quang Hai, deputy manager of the HOSE's brokerage department (2010).

"Equitization" is a Vietnamese-English term that denotes the conversion of a state-owned enterprise in Vietnam into a public limited company or a corporation. 
able in the securities market, where many of the listed companies are current or former SOEs. In which, dividend distribution is likely to be decided beneficially for some specific individuals or groups, instead of the whole. Therefore, we wonder whether the current dividend payout policy of Vietnamese listed companies (especially SOEs firms) could be considered as a dependable signal for investors? Is it affected or controlled by any power behind screen?

The controlling shareholder not only can easily acquire information, but can also decide when or how to introduce the related information to the capital markets. Thus, in Vietnamese listed firms, how the unique ownership structure influences information communication and affects the dividend policy are important issues of management. In addition, before 2009 and during 20112012, Vietnam practiced a zero tax policy on dividends for all local and foreign individual and institutional investors which not only affected the corporate payout policy, but also influenced the information transparency of firms. Therefore, this study aims to examine whether the ownership structure influences the dividend policy of Vietnamese listed firms, and whether the Vietnam's non-zero tax policy affects the relationship between the ownership structure and corporate dividend policy.

We find that, in Vietnam, when ownership concentration is higher, dividend payouts will be higher. The government-controlled firms pay higher dividends than non-government-controlled ones. Listed companies would pay more dividends after IPO or rights offerings. The results indicate that dividend policy is a viable tool for conveying information to the capital market.

In relation to the effect of the change of the dividend tax policy, it has been found that overall effect of the change of the dividend tax policy is significant. We further separated the sample period into two sub-periods with a higher tax rate of $5 \%$, we discovered that when the personal income tax rate is at the higher level of $5 \%$, the sate-owned firms in HOSE would still pay higher dividends, which represents the dividend preferences of the investors, the status of firms' stable development and the effectiveness of national economic policies.

\section{Literature Review}

\subsection{Overview of Vietnamese Market}

According to report of Vietnam's Ministry of Finance, till the end of 2014, there were 672 listed companies and 02 fund stocks (or mutual fund), in which more than $50 \%$ of listed companies formed from equitization of State-owned enterprises. Vietnamese stock market reached of around 1,156,000 billion VND of total market capitalization (at around 55 billion USD), which equal to $32 \%$ of Vietnamese GDP in 2014. In detail, the listed value from HOSE, the major market for large enterprises, handle over 985,258 billion VND, about $78 \%$ of total market capitalization.

According to Vietnamese "Enterprise Law 2005", "Stock owned by state means stock bought and paid for by capital from the government budget, or by 
capital owned by the representative government institutions, or government profit organizations". By that, "The state-owned corporations, or corporative bodies whose stocks are owned over $50 \%$ by the government" (Article 4 ). However, under the amendment on "Enterprise Law 2014", the term of "Stateowned" will only be pronounced for those companies has $100 \%$ capital belongs to government. Also, due to the information asymmetry problem as well as the protection by law in some indispensable industry such as energy, electricity and the related field, information about the proportion of Vietnamese government in capital market and its control to the firm's management decision are not always fully showing to the public. This somehow is trouble to identify and to make a clearly definition of State-owned enterprises in Vietnam's market. Especially when study about the impact of government to firms' strategy, it raises concern about the separation between ownership and management. The equitized SOE's managers combine governmental advice with their firm's operational activities (Gainsborough [2]).

\subsection{Dividend Policy Regulation}

Under current regulation, Vietnamese firms are allowed to retain 100\% their earnings or distribute it in form of cash dividends, stock dividends or share repurchases. The dividend can be distributed if the company may fulfill the following requirements:

1) Fulfillment of all taxes and other compulsory finance obligations.

2) Making appropriate reserve funds for previous losses or possible losses; and

3) After paying dividends, the enterprise is still able to guarantees its financial capacity for payment of all current payable.

According to analysis of Alphonse \& Quoc Trung [3], similarly to other emerging markets, Vietnamese stock market enjoyed a high proportion of paying firms, at 80\% during the period 2006-2011. While, Tran \& Nguyen [4] reveals a stable behaviour in dividend policy of Vietnamese firms. Thus, to encourage more investment in stock market, Vietnamese government provides very attractive tax policy on dividend. It is worthy mentioning that wherever the corporate investors are foreign or domestic entities, they are exempted from tax in Vietnam. In case of individual shareholders, they are currently responsible for a $5 \%$ of Personal Income Tax for the cash dividend received, this is the flat tax rate for both Vietnamese and foreign investor without any consideration of their tax-resident status in Vietnam. Table 1 shows the tax rate on dividend on

Table 1. Vietnamese tax policy on dividend from 2010 to 2014.

\begin{tabular}{|c|c|c|c|c|}
\hline & Before 2009 & $01 / 2010-07 / 2011$ & $8 / 2011-12 / 2012$ & 2013-present \\
\hline Individual investors & $0 \%$ & $5 \%$ & $0 \%$ & $5 \%$ \\
\hline $\begin{array}{c}\text { Corporate investor } \\
\text { (Vietnamese and foreigner) }\end{array}$ & $0 \%$ & $0 \%$ & $0 \%$ & $0 \%$ \\
\hline
\end{tabular}

Source: Circular No. 160/2009/TT-BTC; Circular No. 134/2011/TT-BTC; Decree No. 101/2011/ND-CP and Circular No. 111/2013/TT-BTC. 
different period in Vietnamese market. In some period, the $0 \%$ tax was applied for individual investor in order to support them in economic recession.

\subsection{School of Thought}

The basic theory of dividend and dividend policy were early born since the $50 \mathrm{~s}$ of the last century. Damodaran [5] distinguishes three schools concerns about dividend policy. Starting from some theoretical school of thought which contains several opposing, a variety and plentiful of empirical study system about analyzing dividend payout policy has been developed in the world.

Firstly, according to Miller \& Modigliani [6], dividend does not affect the value of shares (with the assumption of a perfect capital market as non-taxable dividend, and the company may issue additional shares with free cost at any time). Some later experimental studies which deploy some basis change of assumptions about perfect markets, also supports this view of Miller-Modigliani

Secondly, according to Graham \& Dodd [7], if investors prefer dividends (or in the other words, dividend is the signal for future growth), increasing the dividend may increase the shares value. Besides, the high dividend payments in present may reduce the volatility of future cash flows; high payout ratio reduces the cost of capital, thereby, making higher value of shares. Some experimental studies of Gordon [8] and Fisher [9] bring results that support this argument, the regression results show that dividend has greater impact to the share price, compared to the impact of retained earnings.

Thirdly, according to Brennan [10], if dividend tax is higher than income tax from the sale of shares (capital gain), the higher dividend will reduce the value of shares. The company will choose to retain the earnings, in order to increase the income of shareholders. Experimental study of Litzenberger \& Ramaswamy [11] using personal taxes in the US stock market has proved this argument.

Study the case of China, the second largest world's economic (based on GDP ranking 2014), the representative for new economic force, the emerging markets. It is new developing countries with recently open up capital market but high rate of expansion and potential investment opportunities for future benefits. Studying about factors impact on dividend policy in China, there are two interesting points: The ownership structure and the corporate governance. According to Gul [12], a unique feature of the listed companies on China market is that the state owns various levels of the shares in some companies. This is partly because many of the large listed companies are former state owned enterprises (SOEs).

Wang et al. [13] reveals the dividend payment ratios as well as decision of pay dividends tend to rise in Chinese companies with large state ownership. The reason for this result is due to the high dividend payout benefits for the government to use a portion of profits from the business; it also suits to the needs of the state cash as an incentive to maintain state ownership in the business. While, Bradford et al. [14], with sample are China listed companies from 1998 to 2010, show that state-owned companies pay higher dividends than the private companies, 
as the private companies often encounter restricted situations on raising capital from outside sources. Chen et al. [15] shows that the government-controlled companies, highly concentrated companies, and companies after rights issue tend to have higher dividend payout ratios. Their findings support the conjecture that "Tunneling effect" exist in China market, in which dividends are used by controlling shareholders to divert resources from their companies to their own pockets. Vietnamese capital market has similar features to China's, in which they also completed transforms all of SOEs to be the Join-stock companies.

\section{Hypotheses Development}

As mention above, there is a fact that major of current listed companies on Vietnamese stock markets account for the transformed stated-own enterprise (SOEs) and the government remains as the controlling shareholder in many companies. Besides of government, there is a group of people who occupy dominant share of most companies, as the consequences of an early phenomenon since the Vietnamese capital market established. That is the phenomenon of consolidation of shares from company's staff and employees (whom are allowed to buy preferential shares.) For instance, basically, in the joint stock companies which initial SOEs, the senior labors have right to buy a number of shares at preferential prices ( $40 \%$ of successful bid-price). However, concerning about the lack of knowledge in share benefits and ownerships, many workers decided to sell their share immediately and considered the extra as a reward of company for their service, instead of enjoy it as an investment and savings. As a fact, the buyers are often the member of companies' former leaders or those who have financial advantages, in an attempting to hold a certain percentage of the ownership to maintain their management right. Finally, when the companies go listed officially, the majority shares of stock being owned by a number of people or organizations. Therefore, the current company dividend policy has been depended on the decisions of these large shareholders. Focus on the ownership concentration affect to the dividend policy, the researchers derive the first testable Hypothesis $\mathrm{H} 1$ as following.

H1: Companies with high concentrated ownership are likely to pay higher dividends than those with low concentrated ownership.

With the dominant of State in controlling former SOEs in the Vietnamese market, it is necessary to review the studies by some close markets to recognize the impact of government-controlled factor to the dividend policy. Chen et al. [15] finds that dividend payouts increase as the governments owns more shares. Moreover, they suggest that the government pays high dividends to extract the corporate resources. Identically, Bradford [14] in case of China concludes that compared with the privately controlled firms, the state-controlled firms pay higher dividend. Based on the close situation of those countries as the emerging markets, this study makes a developed Hypothesis based on the $\mathrm{H} 1$ in order to investigate the effect of government control to the dividend policy in those Vi- 
etnamese high-concentrated companies. Hence, the developed Hypothesis H2 is presented as below.

H2: The government controlled companies have higher dividend payments than non-government controlled companies.

As many Join-stock companies are often lack of working capital, if companies distribute too much of dividends, obviously they may lack of fund for future growth. Therefore, it pushes up the company to be listed in the market (IPO) as well as conducting new issuance (rights offering). According to Lee \& Xing [16], paying cash dividends with the receipts from these financial activities may harm the negotiable (minority) shareholders. Moreover, as effect of tunneling, the dividends will be distributed more aligned (close) to the time of fund raising from the capital market.

This phenomenon is even more essential to be considered as the Vietnamese have experienced the "bubble burst" stage in the stock market during 2007-2009, as well as the serious affection of world's economic recession in 2008. As they now overcome the hardest situation and move to a recovering stage, there are many firms come back or new joining the security market which create a big number of IPO and right issues after 2009. Can the recovering of "post-crisis" affect the dividend payout? Thus, it makes researcher to develop the third hypothesis.

H3: Companies will pay higher dividends after IPO or rights offerings.

\section{Methodology}

\subsection{Determinants of Dividend Payout}

In this research, we focus on the impact of ownership structure on the high dividend distribution of listed firms, especially those companies which were the former State-owed entities. The research model was built based on a study of Chen et al. [15]. As the dividend yield is considered as a sign of an investors' return and of a company's future prospect, it is chosen as the dependent variable to explain the ownership impact to dividend policy. According to the hypotheses development, three variables are chosen to be the proxies for the ownership dominants: block shareholders (Largest), government-controlled companies ( $\mathrm{Gov}$ ), IPO or rights issues (IPO_RI).

The following multivariate regression model was used to test the determinants of dividend payout of the listed companies in Vietnamese security market:

$$
\begin{aligned}
& \text { Div }_{i t}=\alpha_{0}+\alpha_{1} \text { Largest }_{i t}+\alpha_{2} \text { Size }_{i t}+\alpha_{3} \text { Leverage }_{i t}+\alpha_{4} \text { Std }_{-} \text {Earning }_{i t} \\
& +\alpha_{5} \text { Div_Stock }_{i t}+\alpha_{6} R O E_{i t}+\varepsilon_{i t} \\
& \text { Div }_{i t}=\beta_{0}+\beta_{1} \text { Gov }_{i t}+\beta_{2} \text { Size }_{i t}+\beta_{3} \text { Leverage }_{i t}+\beta_{4} \text { Std }_{-} \text {Earning }_{i t} \\
& +\beta_{5} \text { Div_Stock }_{i t}+\beta_{6} R O E_{i t}+\mu_{i t} \\
& \operatorname{Div}_{i t}=\gamma_{0}+\gamma_{1} I P O_{-} R I_{i t}+\gamma_{2} \text { Size }_{i t}+\gamma_{3} \text { Leverage }_{i t}+\gamma_{4} \text { Std _ Earning } \\
& +\gamma_{5} \text { Div_Stock }_{i t}+\gamma_{6} R O E_{i t}+v_{i t} \text { ? }
\end{aligned}
$$

For specific, the variables using in this research are defined as Table 2. 
Table 2. Definitions of variables.

\begin{tabular}{|c|c|}
\hline Variable & Definition \\
\hline \multicolumn{2}{|c|}{ Dependent variable } \\
\hline Div_Yield & Cash dividends per share/Price per share \\
\hline \multicolumn{2}{|c|}{ Key Testing Variables (Key Proxy) } \\
\hline IPO_RI & $\begin{array}{l}=1 \text { if there is IPO or rights issue in current years or last year } \\
=0 \text { otherwise }\end{array}$ \\
\hline Largest & $\begin{array}{l}=1 \text { if the majority shareholders hold more than } 50 \% \text { of shares } \\
=0 \text { otherwise }\end{array}$ \\
\hline Gov & $\begin{array}{l}=1 \text { if the company's dominant shareholder is the government } \\
=0 \text { otherwise }\end{array}$ \\
\hline \multicolumn{2}{|c|}{ Controlling variables } \\
\hline Size & Natural log of total assets \\
\hline Leverage & Total liabilities/total assets \\
\hline Std Earnings & $\begin{array}{l}\text { Mean absolute deviation from the mean of net income/ } \\
\text { Mean of total assets over the period }\end{array}$ \\
\hline Div_Stock & $\begin{array}{l}=1 \text { if the company distributes the stock dividend in the same year; } \\
=0 \text { otherwise; }\end{array}$ \\
\hline ROE & Net Income/Equity \\
\hline
\end{tabular}

\subsection{Data Collection}

The sample consists of Vietnamese firms listed on HNX and HOSE during 2010 to 2014. All financial and accounting data including ownership and dividends are gathered from the databank of HNX, HOSE as well as the source supplied by Vietstock ${ }^{4}$ company. The companies listed on HOSE and HNX are selected as study subjects. Majority of the listed companies on the HOSE are are large enterprises ${ }^{5}$, alternatively HNX is for SMEs companies. By investigating the data from both places, the researcher can gain briefly view about dividend policy of the whole market at every single level.

Through the development process of the Vietnamese market, it is easy to recognize the unstable growth of the market with the rapidly changing in the number of listed companies, especially during 2000 to 2009 (Figure 1). This is the consequences of the rapid and uncontrolled growth of market size during 2005-2006, followed by the "bubble burst" stage from 2007 to 2009 when the Vietnamese investors were more careful with their investment. Seriously, as the national market was affected by the world's economic crisis. The situation seems to be recovered after 2010, in which the Vietnamese government tried to create a stronger security market with stable growth. This trend can be observed from Figure 1.

Due to the characteristic differences, the financial institutions (banks, insurance companies and other financial institutions) are excluded from the sample,

${ }^{5}$ Top 30 companies with the largest market capitalization in Vietnam are listed on HOSE. 


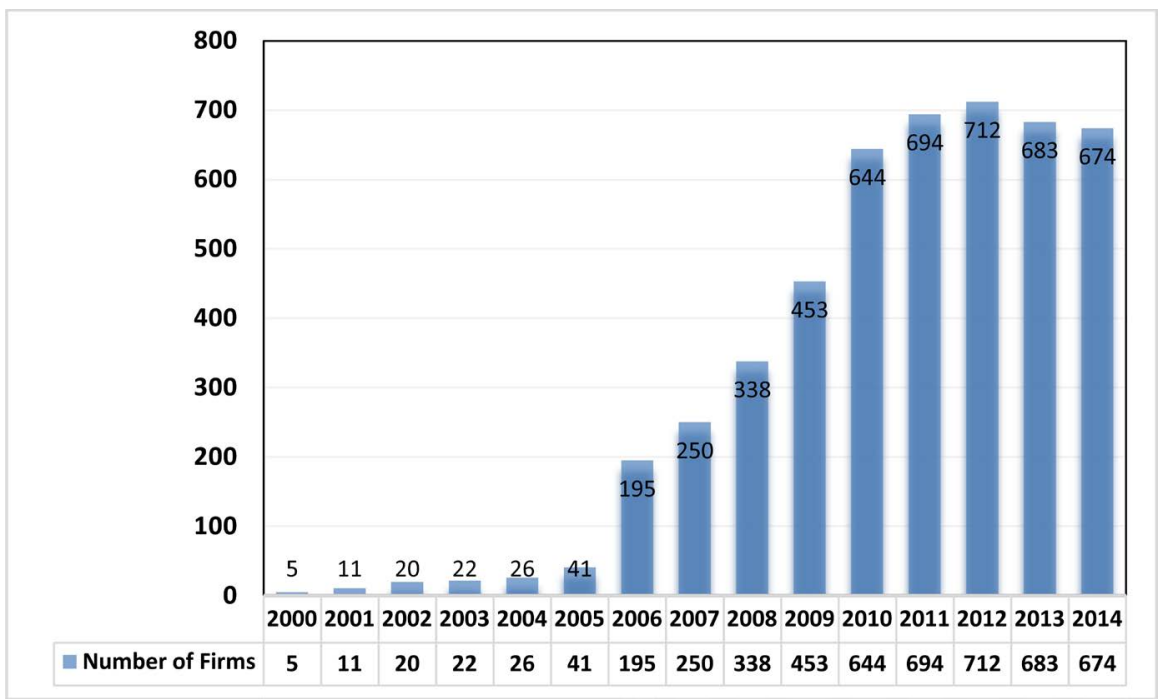

Figure 1. Number of Vietnamese Listed Companies from 2000-2014.

the test using the non-financial observations only. Furthermore, for enhancing the accuracy of research observations and the quality of result finding, the samples are chosen from those companies listed at least 3 years. At the same time, those observations with incomplete information or missing values for the investigation variables were removed from the population.

Specifically, in this research, those companies with annual dividend payout-ratio larger than 1 was excluded from the sample, as this high ratio means the companies spent more than what they can earn (the Earnings) for dividend payment. Explaining for this phenomenon, researchers can assume the company applied some policies such as cumulative dividend. Some companies were even facing an insolvency period and going to bankrupt. This kind of reason makes their payment policy seems to be abnormal. Thus, to ensure the accuracy of the research evaluation, these special treatments were removed from the Sample.

In addition, the researcher used the Industry Classification Benchmark ${ }^{6}$ to illustrate the non-financial observations in different industry sector to clearly classify their decisions about dividend payout policies.

\section{Result and Analysis}

\subsection{General Statistic}

Table 3 presents an overall view of the listed companies' characteristic in HNX. Basically, HNX is the market for Medium and Small size companies. In Panel A, the Median of Dividend Yield at $0.06 \%$ or $6 \%$ is close to its Mean at $0.07 \%$ or $7 \%$ may suggest on average the dividend payment of the Vietnamese listed companies in HNX is quite identical and most of them prefer applying the Low-dividend policy. The dividend at $6 \%$ or $7 \%$ was still considered as Low-dividend based on the comparison with the high interest rate which applied by Banks in Vietnam 6http://www.icbenchmark.com/. 
Table 3. Descriptive Statistic - HANOI STOCK EXCHANCE (HNX)

\begin{tabular}{|c|c|c|c|c|c|c|c|}
\hline \multicolumn{8}{|c|}{ Panel A: General Characteristics - HaNoi Stock Exchange (HNX) } \\
\hline \multicolumn{8}{|c|}{ Sample: $2010-2014$} \\
\hline & Mean & Median & \multicolumn{2}{|c|}{ Maximum } & Minimum & \multicolumn{2}{|c|}{ Observations (N) } \\
\hline DIVIDEND_YIELD & 0.07 & 0.06 & \multicolumn{2}{|c|}{0.46} & 0.00 & \multicolumn{2}{|l|}{1298} \\
\hline LARGEST & 0.46 & 0.00 & \multicolumn{2}{|c|}{1.00} & 0.00 & \multicolumn{2}{|l|}{1298} \\
\hline GOV & 0.50 & 0.50 & \multicolumn{2}{|c|}{1.00} & 0.00 & \multicolumn{2}{|l|}{1298} \\
\hline IPO_RI & 0.49 & 0.00 & \multicolumn{2}{|c|}{1.00} & 0.00 & \multicolumn{2}{|l|}{1298} \\
\hline SIZE & 26.18 & 26.12 & \multicolumn{2}{|c|}{31.04} & 23.18 & \multicolumn{2}{|l|}{1298} \\
\hline LEVERAGE & 0.53 & 0.57 & \multicolumn{2}{|c|}{0.96} & 0.01 & \multicolumn{2}{|l|}{1298} \\
\hline STD_EARNING & 0.00 & 0.00 & \multicolumn{2}{|c|}{0.23} & -0.59 & \multicolumn{2}{|l|}{1298} \\
\hline DIV_STOCK & 0.08 & 0.00 & \multicolumn{2}{|c|}{1.00} & 0.00 & \multicolumn{2}{|l|}{1298} \\
\hline ROE & 9.90 & 10.92 & \multicolumn{2}{|c|}{76.39} & -392.68 & \multicolumn{2}{|l|}{1298} \\
\hline \multicolumn{8}{|c|}{ Panel B: Sample Distribution - HaNoi Stock Exchange (HNX) } \\
\hline \multirow{2}{*}{$\mathrm{HNX}$} & \multicolumn{4}{|c|}{$\begin{array}{l}\text { Industry * GOV } \\
\text { Crosstabulation }\end{array}$} & \multicolumn{3}{|c|}{ Industry ${ }^{*}$ Largest Crosstabulatior } \\
\hline & NO & N GOV & GOV & Total & $\begin{array}{c}\text { NON } \\
\text { LARGEST }\end{array}$ & LARGEST & Total \\
\hline Basic materials & & 88 & 60 & 148 & 91 & 57 & 148 \\
\hline Communication & & 34 & 28 & 62 & 29 & 33 & 62 \\
\hline Consumer goods & & 79 & 44 & 123 & 83 & 40 & 123 \\
\hline $\begin{array}{l}\text { Consumer } \\
\text { services }\end{array}$ & & 68 & 72 & 140 & 82 & 58 & 140 \\
\hline Health care & & 27 & 10 & 37 & 21 & 16 & 37 \\
\hline Industrials & & 329 & 401 & 730 & 345 & 385 & 730 \\
\hline Oil and Gas & & 0 & 15 & 15 & 10 & 5 & 15 \\
\hline Technology & & 24 & 19 & 43 & 34 & 9 & 43 \\
\hline Total & & 649 & 649 & 1298 & 695 & 603 & 1298 \\
\hline
\end{tabular}

during the research period. In detail, from 2010 to 2015, the interest rate had reached over $14 \%^{7}$ due to the high demand for capital of the Vietnamese banks, and this rate only slowed down to 7\% at the end of 2013 to 2014 . However, compare to the Maximum at 0.46 and Minimum at 0.00 , it seems their policy is quite fluctuant. While some companies have extremely high ratio of dividend payout at close to $50 \%$ or the stock price, there are other companies decide to apply the non-cash dividend policy.

Statistics for Independent variables also present in Panel A. In which, Size (natural log of total assets), EP and Leverage has their Mean and Median are almost the same. However, examining the Leverage, it may recognize that the ratio is not too high, on average at $53 \%$ only; this means the listed companies are ${ }^{7}$ http://www.tradingeconomics.com/vietnam/interest-rate. 
willing to raise the fund in the equity market, instead of borrowing money from banks or other financial institutions. Moving to the stock dividend (presents by DIV_STOCK variable), it seems this dividend policy is still a choice for the minority companies, at $8 \%$ only. This may explain for the company policy by focusing on the preference of shareholders to Cash when choosing the dividend payout method. In addition, the government proves its big influence in the market by holding $50 \%$ listed companies. At the same time, the largest shareholder (with shares held exceed 50\%) is at $46 \%$ of total companies.

Comparing the GOV and Largest, it reveals the percentage of State-owned companies is slightly higher than Largest, it means not all of the companies, the Government will keep over $50 \%$ of the shares; however, these companies are still under the State-control. Explanation for this difference may from the regulations of Vietnamese, there are some special fields of business should be partly or even $100 \%$ under the control of government, such as Gas and Oil Industry, Communication, etc. This issue may clearly see on Panel B, which shows the industry and ownership distribution of the sample companies. Among the total sample companies, the Industrials sector seems to occupy the highest percentage; at over $56 \%$ companies are Industrial business. The "Oil and Gas" has the lowest share, at $1.1 \%$ only; however, all of them are under controlled of the State as mention above.

Similarly, Table 4 presents the descriptive statistic for HOSE, which has the majority of companies listed as large enterprises. This issue can be revealed from the Mean of SIZE variable. The SIZE (log natural of Total Asset) of those companies in HOSE is around 27.6, higher than that one in HNX, which is at 26.2 only.

In general, most of ratio in HOSE is quite identical to HNX, instead of some small difference in the ownership and dividend payout method. In HOSE, government and high-concentrated shareholders share smaller proportion, at $44.9 \%$ (453/1008) and 45.3\% (455/1008) respectively. HOSE's listed companies also more enjoy the stock dividend issue at $16.3 \%$, double than that of in HNX. In addition, "Industrial" and "Consumer goods" are sharing the highest number of firms in Industry sector.

Table 5 and Table 6 present the correlation coefficients of the dependent variables and key testing variable, separated by the sample in Ha Noi (HNX) and Ho Chi Minh Stock Exchange (HOSE).

From HNX sample in Table 5, the largest value correlation of key testing variables occurs between GOV and Largest at 0.635 , it presents a strong relationship between the government variable with the majority shareholders in listed companies. An interesting emphasize has been revealed, all of the key explaining for the hypothesis developments (Largest, Gov, IPO_RI) are significant at 10\% level and most of them positively related to the dividend yield. This may be considered as initial evidence to investigate the connection between dividend policy and the concentrated ownership of those listed companies in Ha Noi Securities market. 
Table 4. Descriptive Statistic - HO CHI MINH STOCK EXCHANCE (HOSE)

\begin{tabular}{|c|c|c|c|c|c|c|}
\hline \multicolumn{7}{|c|}{ Panel A: General Characteristics - Ho Chi Minh Stock Exchange (HOSE) } \\
\hline \multicolumn{7}{|c|}{ Sample: $2010-2014$} \\
\hline & Mean & Median & Maximum & Minimun & \multicolumn{2}{|c|}{ Observations $(\mathrm{N})$} \\
\hline DIVIDEND_YIELD & 0.060 & 0.054 & 0.359 & 0.000 & \multicolumn{2}{|c|}{1008.} \\
\hline LARGEST & 0.453 & 0.000 & 1.000 & 0.000 & \multicolumn{2}{|c|}{1008} \\
\hline GOV & 0.449 & 0.000 & 1.000 & 0.000 & \multicolumn{2}{|c|}{1008} \\
\hline IPO_RI & 0.563 & 1.000 & 1.000 & 0.000 & \multicolumn{2}{|c|}{1008} \\
\hline SIZE & 27.553 & 27.431 & 31.616 & 25.050 & \multicolumn{2}{|c|}{1008} \\
\hline LEVERAGE & 0.482 & 0.500 & 0.967 & 0.002 & \multicolumn{2}{|c|}{1008} \\
\hline STD_EARNING & 0.001 & 0.000 & 0.244 & -0.638 & \multicolumn{2}{|c|}{1008} \\
\hline DIV_STOCK & 0.163 & 0.000 & 1.000 & 0.000 & \multicolumn{2}{|c|}{1008} \\
\hline ROE & 10.888 & 12.442 & 63.558 & -783.637 & \multicolumn{2}{|c|}{1008} \\
\hline \multicolumn{7}{|c|}{ Panel B: Sample Distribution - Ho Chi Minh Stock Exchange (HOSE) } \\
\hline \multirow[t]{2}{*}{ HOSE } & \multicolumn{3}{|c|}{$\begin{array}{l}\text { Industry * GOV } \\
\text { Crosstabulation }\end{array}$} & \multicolumn{3}{|c|}{$\begin{array}{l}\text { Industry }{ }^{*} \text { Largest } \\
\text { Crosstabulation }\end{array}$} \\
\hline & $\begin{array}{l}\text { NON } \\
\text { GOV }\end{array}$ & GOV & Total & $\begin{array}{c}\text { NON } \\
\text { LARGEST }\end{array}$ & LARGEST & Total \\
\hline Basic materials & 121 & 65 & 186 & 111 & 75 & 186 \\
\hline Communication & 34 & 5 & 39 & 39 & 0 & 39 \\
\hline Consumer goods & 175 & 62 & 237 & 144 & 93 & 237 \\
\hline $\begin{array}{l}\text { Consumer } \\
\text { services }\end{array}$ & 23 & 34 & 57 & 28 & 29 & 57 \\
\hline Health care & 34 & 14 & 48 & 44 & 4 & 48 \\
\hline Industrials & 160 & 197 & 357 & 172 & 185 & 357 \\
\hline Oil and Gas & 0 & 5 & 5 & 0 & 5 & 5 \\
\hline Technology & 8 & 71 & 79 & 15 & 64 & 79 \\
\hline Total & 555 & 453 & 1008 & 553 & 455 & 1008 \\
\hline
\end{tabular}

Identically, Table 6 indicates the correlation between testing variable using HOSE observation. Basically, it presents similar trend with HNX in the correlation between those key testing variable and the dependent variable (Dividend Yield), except for IPO_RI.

\subsection{Empirical Results}

Table 7 shows the determinants of dividend payout policy to test for the precision of Hypothesis 1, 2 and 3. The negative siginificant between SIZE and Dividend reveals that the larger firms with better accounting performance on Asset are likely to pay lower dividend. However, the difference between companies' dividend in case of SIZE is very small, at $0.007 \%$ only.

With the positive coefficient in LEV variable, the more debt comapnies use, 
Table 5. Correlation analysis - HA NOI STOCK EXCHANCE (HNX).

\begin{tabular}{|c|c|c|c|c|c|c|c|c|c|}
\hline Probability & DIV_YIELD & LARGEST & GOV & IPO_RI & SIZE & LEV & STD_EARNING & DIV_STOCK & ROE \\
\hline \multirow[t]{2}{*}{ DIV_YIELD } & 1.000 & & & & & & & & \\
\hline & ---- & & & & & & & & \\
\hline \multirow[t]{2}{*}{ LARGEST } & 0.057 & 1.000 & & & & & & & \\
\hline & $(0.039)$ & ---- & & & & & & & \\
\hline \multirow[t]{2}{*}{ GOV } & 0.068 & 0.635 & 1.000 & & & & & & \\
\hline & $(0.014)$ & $(0.000)$ & ----- & & & & & & \\
\hline \multirow[t]{2}{*}{ IPO_RI } & 0.052 & -0.079 & -0.105 & 1.000 & & & & & \\
\hline & $(0.060)$ & $(0.004)$ & $(0.000)$ & ---- & & & & & \\
\hline \multirow[t]{2}{*}{ SIZE } & -0.033 & 0.006 & 0.120 & 0.106 & 1.000 & & & & \\
\hline & $(0.235)$ & $(0.832)$ & $(0.000)$ & $(0.000)$ & ----- & & & & \\
\hline \multirow[t]{2}{*}{ LEV } & 0.055 & 0.128 & 0.110 & 0.015 & 0.576 & 1.000 & & & \\
\hline & $(0.050)$ & $(0.000)$ & $(0.000)$ & $(0.582)$ & $(0.000)$ & ----- & & & \\
\hline \multirow[t]{2}{*}{ STD_EARNing } & 0.170 & -0.006 & -0.010 & 0.128 & 0.034 & -0.054 & 1.000 & & \\
\hline & $(0.000)$ & $(0.830)$ & $(0.718)$ & $(0.000)$ & $(0.216)$ & $(0.052)$ & ----- & & \\
\hline \multirow[t]{2}{*}{ DIV_STOCK } & 0.000 & -0.016 & -0.025 & 0.288 & 0.035 & 0.001 & 0.069 & 1.000 & \\
\hline & $(0.989)$ & $(0.571)$ & $(0.360)$ & $(0.000)$ & $(0.212)$ & $(0.970)$ & $(0.013)$ & ---- & \\
\hline \multirow[t]{2}{*}{$\mathrm{ROE}_{-}$} & 0.345 & 0.037 & 0.007 & 0.114 & 0.039 & -0.066 & 0.569 & 0.097 & 1.000 \\
\hline & $(0.000)$ & $(0.186)$ & $(0.798)$ & $(0.000)$ & $(0.161)$ & $(0.018)$ & $(0.000)$ & $(0.001)$ & ---- \\
\hline
\end{tabular}

Note: The p-value are reported in parentheses

Table 6. Correlation analysis - HO CHI MINH STOCK EXCHANCE (HOSE).

\begin{tabular}{|c|c|c|c|c|c|c|c|c|c|}
\hline Probability & DIV_YIELD & LARGEST & GOV & IPO_RI & SIZE & LEV & STD_EARNING & DIV_STOCK & $\mathrm{ROE}$ \\
\hline \multirow[t]{2}{*}{ DIV_YIELD } & 1.000 & & & & & & & & \\
\hline & ---- & & & & & & & & \\
\hline \multirow[t]{2}{*}{ LARGEST } & 0.147 & 1.000 & & & & & & & \\
\hline & $(0.000)$ & ---- & & & & & & & \\
\hline \multirow[t]{2}{*}{ GOV } & 0.184 & 0.545 & 1.000 & & & & & & \\
\hline & $(0.000)$ & $(0.000)$ & ---- & & & & & & \\
\hline \multirow[t]{2}{*}{ IPO_RI } & 0.049 & -0.118 & -0.130 & 1.000 & & & & & \\
\hline & $(0.117)$ & $(0.000)$ & $(0.000)$ & ---- & & & & & \\
\hline \multirow[t]{2}{*}{ SIZE } & -0.114 & 0.012 & 0.009 & 0.134 & 1.000 & & & & \\
\hline & $(0.000)$ & $(0.708)$ & $(0.765)$ & $(0.000)$ & $-\cdots--$ & & & & \\
\hline \multirow[t]{2}{*}{ LEV } & -0.089 & -0.037 & 0.001 & -0.027 & 0.326 & 1.000 & & & \\
\hline & $(0.005)$ & $(0.241)$ & $(0.976)$ & $(0.385)$ & $(0.000)$ & ---- & & & \\
\hline \multirow[t]{2}{*}{ STD_EARNing } & 0.184 & 0.025 & 0.011 & 0.105 & 0.020 & -0.146 & 1.000 & & \\
\hline & $(0.000)$ & $(0.421)$ & $(0.721)$ & $(0.001)$ & $(0.520)$ & $(0.000)$ & ---- & & \\
\hline \multirow[t]{2}{*}{ DIV_STOCK } & -0.068 & -0.088 & -0.106 & 0.345 & 0.145 & -0.034 & 0.049 & 1.000 & \\
\hline & $(0.032)$ & $(0.005)$ & $(0.001)$ & $(0.000)$ & $(0.000)$ & $(0.283)$ & $(0.119)$ & ---- & \\
\hline \multirow[t]{2}{*}{$\mathrm{ROE}_{-}$} & 0.224 & 0.052 & 0.047 & 0.107 & 0.063 & -0.196 & 0.594 & 0.052 & 1.000 \\
\hline & $(0.000)$ & $(0.097)$ & $(0.135)$ & $(0.001)$ & $(0.044)$ & $(0.000)$ & $(0.000)$ & $(0.098)$ & ----- \\
\hline
\end{tabular}

Note: The p-value are reported in parentheses. 
Table 7. Determinants of Dividend Payout Policy_HA NOI STOCK EXCHANCE (HNX).

\begin{tabular}{|c|c|c|c|c|c|c|c|c|c|}
\hline \multicolumn{10}{|c|}{$\begin{array}{c}\text { Dependent Variable: DIVIDEND _ YIELD } \\
\text { Testing for Hypothesis } 1,2 \& 3\end{array}$} \\
\hline \multirow{2}{*}{ Variables } & \multicolumn{3}{|c|}{ Model 1 Largest } & \multicolumn{3}{|c|}{ Model 2 GOV } & \multicolumn{3}{|c|}{ Model 3 IPO_RI } \\
\hline & Coef. & $\mathrm{t}$-value & Sig (P) & Coef. & $\mathrm{t}$-value & Sig (P) & Coef. & $\mathrm{t}$-value & $\operatorname{Sig}(\mathrm{P})$ \\
\hline LARGEST & 0.003 & 0.923 & 0.356 & & & & & & \\
\hline GOV & & & & 0.01 & 2.493 & 0.013 & & & \\
\hline$I P O \_R I$ & & & & & & & 0.005 & 1.373 & 0.170 \\
\hline SIZE & -0.007 & -4.171 & 0.000 & -0.007 & -4.442 & 0.000 & -0.007 & -4.388 & 0.000 \\
\hline$L E V$ & 0.048 & 4.701 & 0.000 & 0.049 & 4.786 & 0.000 & 0.050 & 4.959 & 0.000 \\
\hline STD_EARNing & -0.045 & -0.997 & 0.319 & -0.044 & -0.983 & 0.326 & -0.051 & -1.121 & 0.262 \\
\hline DIV_STOCK & -0.008 & -1.132 & 0.258 & -0.007 & -1.077 & 0.282 & -0.010 & -1.484 & 0.138 \\
\hline$R O E_{-}$ & 0.001 & 12.006 & 0.000 & 0.001 & 12.062 & 0.000 & 0.001 & 12.048 & 0.000 \\
\hline Constant & 0.214 & 5.150 & 0.000 & 0.222 & 5.388 & 0.000 & 0.222 & 5.366 & 0.000 \\
\hline Observations & 1298 & & & 1298 & & & 1298 & & \\
\hline Adj $R^{2}$ & 0.14 & & & 0.14 & & & 0.14 & & \\
\hline
\end{tabular}

the higher dividend they pay. It suggests the idea that the company is running well, thus makes them use debt as a channel for further investment in-need. However, leverage level need to be concerned to avoid of financial risk.

In all case, the ROE is positive significant with dividend yield, while the coefficient of STD_Earning is insignificant. Otherwise, the controlling variables DIV_STOCK (dummy) has insignificantly negative coefficient with the dependent variable in every models.

Analyzing the hypothesis testing for the determinants of dividend yield, only the Government controlled companies (Model 2) consistent with research's Hypotheses (possitvie significant at 5\%). In detail, SOEs tend to distribute higher ratio of dividend, by $0.01 \%$ more dividend than Private-owned firms. Even the difference between those companies with quite small, at around $0.01 \%$ only, but with the huge number of outstanding shares in the market, at dozens or hundreds millions share per company, the total cash companies need to spend for dividend will be a big number. This may confirm the research assumption that dividend is an important to distribte cash which preferd by state-owned firms.

The results in Model 1 showing that high concentrated ownership companies will pay $0,003 \%$ higher dividend than the Low-concentrated one. However, the p-value of the Largest testing variable is higher than 0.1 (at significant level of $10 \%)$, making it become insignificant. Or it means the Hypothesis 1 is not supported in HaNoi market. It does not have enough evidence to say the Highconcentrated firms in HNX tend to pay more dividend.

Using the output from Table 8 to identify with the trend appears in Ho Chi Minh Stock Exchange. Different with HNX result, it can be clearly seen that all 
Table 8. Determinants of Dividend payout policy_HO CHI MINH STOCK EXCHANCE (HOSE).

\begin{tabular}{cccccccccccc}
\hline \multirow{8}{*}{ Variables } & \multicolumn{7}{c}{$\begin{array}{c}\text { Dependent Variable: DIVIDEND _ YIELD } \\
\text { Testing for Hypothesis 1, 2 \& 3 }\end{array}$} \\
\cline { 2 - 10 } & Coef. & t-value & Sig (P) & Coef. & t-value & Sig (P) & Coef. & t-value & Sig (P) \\
\hline LARGEST & 0.016 & 4.444 & 0.000 & & & & & & \\
GOV & & & & 0.021 & 5.681 & 0.000 & & & \\
IPO_RI & & & & & & & 0.008 & 2.085 & 0.037 \\
SIZE & -0.006 & -3.751 & 0.000 & -0.006 & -3.734 & 0.000 & -0.007 & -3.743 & 0.000 \\
LEV & 0.000 & 0.040 & 0.968 & -0.001 & -0.139 & 0.889 & -0.001 & -0.081 & 0.936 \\
STD_EARNing & 0.092 & 2.093 & 0.037 & 0.095 & 2.179 & 0.030 & 0.086 & 1.946 & 0.052 \\
DIV_STOCK & -0.008 & -1.674 & 0.094 & -0.007 & -1.477 & 0.140 & -0.014 & -2.654 & 0.008 \\
ROE_ & 0.000 & 4.753 & 0.000 & 0.000 & 4.673 & 0.000 & 0.000 & 4.819 & 0.000 \\
Constant & 0.228 & 4.955 & 0.000 & 0.225 & 4.914 & 0.000 & 0.234 & 5.036 & 0.000 \\
Observations & 1008 & & & 1008 & & & 1008 & & \\
Adj $R^{2}$ & 0.09 & & & 0.10 & & & 0.073 & & \\
\hline
\end{tabular}

of testing results using HOSE observations are consistent with the assumptions in hypotheses 1, 2 and 3. All of expected statistics are positively significant with dividend yield. In detail, the companies with largest shareholder (occupy over $50 \%$ shares) will distribute $0.016 \%$ dividend rate higher than those companies without majority controller. For Model 2, the state-owned firms are more likely to distribute more cash dividend to tunnel the companies' resources, with $0.021 \%$ higher than non-State controlled firms. At the same time, those new joining companies in the market or with rights issues within the last two years, with the additional capital rising from equity market, also spend $0.008 \%$ more in their dividend payout policies, coefficients are significant at the $1 \%$ or $5 \%$ levels,

An interesting comparison between HNX and HOSE is that even the percentage of high-controlled ownership or government-controlled firms in HOSE is lower than that of HNX. However, those concentrated ownership and government-owned companies in HOSE are presenting more interest in high dividend payment policies, comparing to the other listed companies in HNX. As the fact have been mentioned before, HOSE is considered as the market for large companies, automatically the companies' behavior in policy applying will make more influence on the whole national securities market.

In order to wonder the effect of tax policy in different period may effect the dividend policy, esspecially during 2012, Vietnamese government applied the zero dividend tax policy for individual investor in order to push up the invesment after the economic recession. Hence, we decided to make some sub test using the two sub sample from 2010-2011 and 2013-2014 when individual tax dividend constant at $5 \%$ for the two main group Gov and Largest. These test 
help identifing any different in the decision of dominant group to company policies between before and after the low tax applied.

From Table 9 and Table 10, it seems in all case, the coefficient of state-owned and largest group is possitive with the dividend payment, but only result in HOSE is significant. In particular, in HOSE, the State-owned group has possitive relationship with dividend yeild in both period before and after the zero tax in 2012. At the same time, Largest group shows significant possitive results in 2013-2014 only. It means those companies dominated by government or larger group of shareholres seems to pay more dividend when comparing to the other institutions in market. Explain for phenomenon, we must mention that the HOSE is the market for big companies which mostly are blue chip stocks. Firms

Table 9. Determinants of Dividend Payout Policy_HANOI STOCK EXCHANCE (HNX).

\begin{tabular}{|c|c|c|c|c|c|c|}
\hline \multicolumn{7}{|c|}{ Dependent Variable: DIVIDEND_YIELD_Testing for Hypothesis 1, 2} \\
\hline \multirow{2}{*}{$\begin{array}{c}\text { Panel A: } \\
\text { Sub sample: 2010-2011 } \\
\text { Variables }\end{array}$} & \multicolumn{3}{|c|}{ Model 1 Largest } & \multicolumn{3}{|c|}{ Model 2 ( GOV) } \\
\hline & Coef. & $\mathrm{t}$-value & Sig $(P)$ & Coef. & $\mathrm{t}$-value & Sig $(P)$ \\
\hline LARGEST & 0.002 & 0.318 & 0.751 & & & \\
\hline$G O V$ & & & & 0.008 & 1.213 & 0.226 \\
\hline SIZE & -0.009 & -2.659 & 0.008 & -0.009 & -2.789 & 0.006 \\
\hline$L E V$ & 0.038 & 1.925 & 0.055 & 0.038 & 1.962 & 0.050 \\
\hline STD_EARNing & -0.486 & -4.915 & 0.000 & -0.478 & -4.835 & 0.000 \\
\hline DIV_STOCK & -0.018 & -1.757 & 0.080 & -0.018 & -1.750 & 0.081 \\
\hline$R O E_{-}$ & 0.003 & 10.261 & 0.000 & 0.003 & 10.240 & 0.000 \\
\hline Constant & 0.255 & 3.263 & 0.001 & 0.262 & 3.378 & 0.001 \\
\hline Observations & 502 & & & 502 & & \\
\hline Adj $R^{2}$ & 0.18 & & & 0.18 & & \\
\hline $\begin{array}{c}\text { Panel B: } \\
\text { Sub sample: 2013-2014 }\end{array}$ & \multicolumn{3}{|c|}{ Model 1 Largest } & \multicolumn{3}{|c|}{ Model 2 ( GOV) } \\
\hline Variables & Coef. & $\mathrm{t}$-value & Sig (P) & Coef. & t-value & Sig $(P)$ \\
\hline$L A R G E S T$ & 0.003 & 0.637 & 0.524 & & & \\
\hline$G O V$ & & & & 0.006 & 1.281 & 0.201 \\
\hline SIZE & -0.003 & -1.580 & 0.115 & -0.003 & -1.721 & 0.086 \\
\hline$L E V$ & 0.027 & 2.224 & 0.027 & 0.027 & 2.306 & 0.022 \\
\hline STD_EARNing & -0.002 & -0.053 & 0.958 & -0.005 & -0.097 & 0.923 \\
\hline DIV_STOCK & -0.011 & -1.273 & 0.204 & -0.011 & -1.227 & 0.221 \\
\hline$R O E_{-}$ & 0.001 & 6.273 & 0.000 & 0.001 & 6.338 & 0.000 \\
\hline Constant & 0.113 & 2.352 & 0.019 & 0.118 & 2.476 & 0.014 \\
\hline Observations & 526 & & & 526 & & \\
\hline Adj $R^{2}$ & 0.09 & & & 0.09 & & \\
\hline
\end{tabular}


Table 10. Determinants of Dividend Payout Policy_HOCHIMINH STOCK EXCHANCE (HOSE)

\begin{tabular}{|c|c|c|c|c|c|c|}
\hline \multicolumn{7}{|c|}{ Dependent Variable: DIVIDEND__YIELD_Testing for Hypothesis 1, 2} \\
\hline \multirow{2}{*}{$\begin{array}{c}\text { Panel A: } \\
\text { Sub sample: } 2010-2011 \\
\text { Variables }\end{array}$} & \multicolumn{3}{|c|}{ Model 1 Largest } & \multicolumn{3}{|c|}{ Model 2 ( GOV) } \\
\hline & Coef. & t-value & Sig (P) & Coef. & $\mathrm{t}$-value & Sig (P) \\
\hline$L A R G E S T$ & 0.009 & 1.324 & 0.186 & & & \\
\hline GOV & & & & 0.015 & 2.266 & 0.024 \\
\hline SIZE & -0.011 & -3.474 & 0.001 & -0.011 & -3.488 & 0.001 \\
\hline$L E V$ & 0.029 & 1.735 & 0.084 & 0.028 & 1.695 & 0.091 \\
\hline STD_EARNing & -0.150 & -1.576 & 0.116 & -0.124 & -1.295 & 0.196 \\
\hline DIV_STOCK & -0.021 & -2.478 & 0.014 & -0.020 & -2.356 & 0.019 \\
\hline$R O E_{-}$ & 0.002 & 7.153 & 0.000 & 0.002 & 6.850 & 0.000 \\
\hline Constant & 0.346 & 3.960 & 0.000 & 0.344 & 3.956 & 0.000 \\
\hline Observations & 376 & & & 376 & & \\
\hline Adj $R^{2}$ & 0.18 & & & 0.18 & & \\
\hline $\begin{array}{c}\text { Panel B: } \\
\text { Sub sample: } 2013-2014\end{array}$ & \multicolumn{3}{|c|}{ Model 1 Largest } & \multicolumn{3}{|c|}{ Model 2 (GOV) } \\
\hline Variables & Coef. & $\mathrm{t}$-value & Sig (P) & Coef. & $\mathrm{t}$-value & Sig $(P)$ \\
\hline$L A R G E S T$ & 0.019 & 4.687 & 0.000 & & & \\
\hline$G O V$ & & & & 0.021 & 5.170 & 0.000 \\
\hline SIZE & -0.002 & -1.194 & 0.233 & -0.002 & -1.112 & 0.267 \\
\hline$L E V$ & -0.011 & -1.161 & 0.246 & -0.013 & -1.314 & 0.190 \\
\hline STD_EARNing & -0.041 & -0.846 & 0.398 & -0.051 & -1.059 & 0.290 \\
\hline DIV_STOCK & 0.006 & 1.069 & 0.286 & 0.008 & 1.379 & 0.169 \\
\hline$R O E_{-}$ & 0.000 & 3.316 & 0.001 & 0.000 & 3.438 & 0.001 \\
\hline Constant & 0.095 & 1.963 & 0.050 & 0.091 & 1.873 & 0.062 \\
\hline Observations & 420 & & & 420 & & \\
\hline Adj $R^{2}$ & 0.08 & & & 0.09 & & \\
\hline
\end{tabular}

with dominance of State are willing to attract more capital into their business, hence they have to make some positive signals to the market. It is consistent with other studies using Vietnamese market data, in which firms with high state ownership often have better financial performance (Le \& Tannous [17]; Phung \& Mishra [18]; Quang \& $\mathrm{Wu}$ [19]). These results magnify the effectiveness of the government policy.

\section{Conclusions}

This research contributes to the limited study on the link between the ownerships, the government role, the capital raising activities, the future growth and 
dividend payout policy of the listed companies within the context of a single country, Vietnam. The study highlights the importance of distinguishing the playing-roles between the majority and the minority shareholders, between private and state controlled firms.

The majority shareholders seem to have incentive to distribute high dividends because of their disproportionate high investment return, which is risky to the minority shareholders due to their low influence on management policy decision and lack of legal protection. Morever, the empirical results reveal evidence to believe the existence of the high dividend policy in those companies which formerly are state-owned. The government controlled companies pay higher dividends than the non-government organizations.

Furthermore, combined with the different dividend tax treatments in Vietnamese market from 2010 to 2015, we find an interesting point that even in period of higher tax issue, state-owned enterprise still more prefers in paying high dividend, as a method to encourage the shareholder to secure in their investment. At the same time, it is used as good evidence to the efficiency of government policy in economic control, which is consistent with the long-term development policy, the Renewal process of the Vietnamese government. With the high advance on investment opportunities, Vietnamese SOEs tend to spend more capital to future project, rather than to pay dividend. However, they still maintain a positive level of dividend payout, which keeps (maintains) the stock attractiveness to dividend preferred investors.

We encourage the Vietnamese government to maintain their controlling on dividend policy to ensure this financial activities as a precise signal to investors, which is beneficial to the long-term development. It is suggested that to reduce the unfair treatment for minority shareholders, thus the negative effects on the security market would be mitigated and the public governance quality would be improved.

\section{Conflicts of Interest}

The authors declare no conflicts of interest regarding the publication of this paper.

\section{References}

[1] Nguyen, T.T. and Van Dijk, M. (2012) Corruption, Growth, and Governance: Private vs. State-Owned Firms in Vietnam. Journal of Banking \& Finance, 36, 2935-2948. https://doi.org/10.1016/j.jbankfin.2012.03.027

[2] Gainsborough, M. (2009) Privatisation as State Advance: Private Indirect Government in Vietnam. New Political Economy, 14, 257-274. http://dx.doi.org/10.1080/13563460902826013

[3] Alphonse, P. and Quoc Trung, T. (2014) A Two-Step Approach to Investigate Dividend Policy: Evidence from Vietnamese Stock Market. International Journal of Economics and Finance, 6. https://doi.org/10.5539/ijef.v6n3p16

[4] Tran, Q.T. and Nguyen, T.T.H. (2004) Dividend Policy Behavior in Emerging Stock 
Markets: Evidence from Vietnamese Stock Market. International Journal of Financial Research, 5, 85-89. https://doi.org/10.5430/ijfr.v5n4p85

[5] Damodaran, A. (2001) Corporate Finance: Theory and Practice. 2nd International Edition, John Wiley \& Sons, New York.

[6] Miller, M. and Modigliani, F. (1961) Dividend Policy, Growth, and the Valuation of Shares. Journal of Business, 34, 411-433. https://doi.org/10.1086/294442

[7] Graham, B. and Dodd, D.L. (1951) Security Analysis. McGraw-Hill, New York.

[8] Gordon, M.J. (1959) Dividends, Earnings, and Stock Prices. The Review of Economics and Statistics, 41, 99-105. https://doi.org/10.2307/1927792

[9] Fisher G.R. (1961) Some Factors Influencing Share Prices. Economic Journal, 71, 121-141. https://doi.org/10.2307/2228227

[10] Brennan, M. (1970) Tax, Market Valuation, and Corporate Financial Policy. National Tax Journal, 23, 417-427.

[11] Litzenberger, R.H. and Ramaswamy, K. (1979) The Effect of Personal Taxes and Dividends on Capital Asset Prices. Journal of Financial Economics, 7, 163-195. https://doi.org/10.1016/0304-405X(79)90012-6

[12] Gul, F.A. (1999) Government Share Ownership, Investment Opportunity Set and Corporate Policy Choices in China. Pacific-Basin Finance Journal, 7, 157-172. https://doi.org/10.1016/S0927-538X(99)00004-9

[13] Wang, X., Manry, D. and Wandler, S. (2011) The Impact of Government Ownership on Dividend Policy in China. Advances in Accounting, 27, 366-372. https://doi.org/10.1016/j.adiac.2011.08.003

[14] Bradford, W., Chao, C. and Song, Z. (2013) Cash Dividend Policy, Corporate Pyramids, and Ownership Structure: Evidence from China. International Review of Economics \& Finance, 27, 445-464. https://doi.org/10.1016/j.iref.2013.01.003

[15] Chen, D.H., Ming, J. and Ming, X. (2009) Dividends for Tunneling in a Regulated Economy: The Case of China. Pacific-Basin Finance Journal, 17, 209-223. https://doi.org/10.1016/j.pacfin.2008.05.002

[16] Lee, C.J. and Xing, X. (2004) Tunneling Dividends. SSRN Scholarly Paper. Social Science Research Network, Rochester, NY. https://doi.org/10.2139/ssrn.693361

[17] Le, T.P.V. and Tannous, K. (2016) Ownership Structure, Capital Structure and Firm Performance: A Study of Vietnamese Listed Firms. Australian Economic Papers, 55, 319-344. https://doi.org/10.1111/1467-8454.12089

[18] Phung, D.N. and Mishra, A.V. (2016) Ownership Structure and Firm Performance: Evidence from Vietnamese Listed Firms. Australian Economic Papers, 55, 63-98. https://doi.org/10.1111/1467-8454.12056

[19] Quang, D.X. and Wu, Z.X. (2014) The Impact of Ownership Structure and Capital Structure on Financial Performance of Vietnamese Firms. International Business Research, 7. https://doi.org/10.5539/ibr.v7n2p64 